\title{
Web-based Fuzzy Expert System for Symptomatic Risk Assessment of Diabetes Mellitus
}

\author{
I. K. Mujawar \\ Department of Computer Science, \\ Vivekanand College \\ Kolhapur, India
}

\author{
B. T. Jadhav, PhD \\ Department of Electronics and \\ Computer Science, YCIS \\ Satara, India.
}

\author{
Kapil Patil, PhD \\ 'Swad' Diabetes Care Centre \\ Sangli, India
}

\begin{abstract}
Web applications have demonstrated their assistance as helping tools for therapeutic specialists, experts and patients as well. The uses of the Internet-based innovations and the ideas of fuzzy expert system (FES) have made new strategies for sharing and circulating information. This study intends to build rule based online fuzzy expert system which assist people around the globe during the time spent management of diabetes mellitus. The proposed work presents web based expert system (Web-FESSRADM) for individuals who can check their diabetes risk and for doctors, practitioners to assess diabetes risk online. In the Web-FESSRADM development fuzzy logic approach is utilized to determine the risk of diabetes. Open source software development environment is used to develop and actualize proposed work.
\end{abstract}

\section{Keywords}

Diabetes, T1DM, T2DM, Fuzzy Logic, Web Expert System Rule based Fuzzy System.

\section{INTRODUCTION}

Diabetes mellitus:

The pervasiveness of diabetes disease has achieved scourge extents worldwide with the biggest increment in all parts of world including Asia continent too. Diabetes in India is a developing zone of Research as statistically the number has expanded essentially over the most recent years. Diabetes Mellitus is a group of metabolic diseases characterized by hyperglycemia due to insufficient insulin action. The feature of this group of diseases is a deficiency of insulin. The decrease in the insulin supply and decreased insulin sensitivity contributes in insufficient insulin supply [1].

Types of Diabetes:

Etiological classification of diabetes mellitus uses terms type1 and type2. In recent times many forms of diabetes with genetic abnormalities have been identified [1]. American Diabetes Association proposed the etiological classification of diabetes into four major types and it is as type 1 diabetes mellitus (T1DM), type2 diabetes mellitus (T2DM i.e. non-insulin dependent diabetes mellitus or NIDDM), gestational and secondary to other diseases.

Diabetes Complications:

Diabetes complications are divided into acute and chronic complications. Acute complication includes keto acidoses and non-ketotic hyper-osmolar state. Chronic complications again categorized into vascular and non vascular complications. The vascular complications again divided into micro vascular (retinopathy, nephropathy, nephropathy) and macro vascular (artery and cerebro vascular disease). In non vascular complications skin problems, sex disfunctioning are few examples [12]. The macular edema cataracts, glaucoma, kidney disease, and oral complications because of diabetes are also diabetes complications [1].
Web based Expert Systems:

Web centered information and communication technologies are changing Expert System applications [13]. Fast advances in Internet innovations have opened new doors for upgrading customary Decision Support Systems and Expert Systems [14]. The internet provides platform for implementing expert systems including applications from medicine area by offering advantages in accessibility, interfaces and development environments [15]. The web based expert systems demonstrate the advantages in information obtaining, representation, validation and even in inferencing and in the system implementation and maintenance. Selection of expert system development methodology and environment plays pivotal role in the successful development and implementation of web based expert systems [16]. Web based expert system are merging of designing of expert system and web application together. Such developments can be considered as web engineering applications [4].

This research work proposes online expert system application (Web-FESSRADM) which uses fuzzy logic for drawing diabetes risk assessment. Proposed Fuzzy Expert System (FES) developed with aim of providing online platform for people, doctors, practitioners and experts to check symptomatic diabetes risk. Remaining research paper is organized as Section 2 includes Background Study, Section 3 includes Design of Web-FESSRADM, Section 4 includes system development, Section 5 includes Result and Discussion and in Section 6 conclusion is given.

\section{BACKGROUND STUDY}

In the field of oriental medicine most medical concepts and process are in the form of fuzzy. Uncertain nature in medical concepts, processes and their relationships needs use of fuzzy logic [8]. The work presented in research paper [3] is web based expert system for fish diseases. It helps farmers to identify 126 different fish diseases of 9 freshwater fish categories. The three layer architecture was adopted to design this system. Users of this system query and provide the input to the system using different interfaces and system provides results by combining symptoms, water inspections and microscopic tests. Research work in [2] presents online decision support system for Typhoid Fever and utilizes fuzzy inference mechanism with Root Sum Square technique for resulting conclusion. Proposed system was developed with open source development environment using PHP, MySQL JavaScript, AJAX and HTML. The work proposed in [7] is Chinese Medical Diagnostic System (CMDS) utilizes web based user interface and expert system technology to diagnose digestive diseases. Proposed work can diagnose around 50 types of digestive diseases by using 500 rules and 600 images of different diseases. Java Expert System Shell (JESS) was used to develop proposed CMDS. The web-based fuzzy expert system presented in [11] for human disease diagnosis which assists users to diagnose disease using fuzzy way. A 
decision support system using fuzzy logic designed in [5] for disease diagnosis where kidney stone and kidney infection were taken as case studies. Proposed work considers uncertainty of user inputs. Symptoms of kidney stone and kidney infection are used with linguistic and numeric weights. Fuzzy Logic approach is used in [9],[10] for designing expert systems for malaria and heart failure disease where fuzzy inference with Root Sum Square technique is used. Research work presented in [17] is web based expert system designed for diseases like Attention Deficit Hyperactivity Disorder Sleep Apnea and Irritable Bowel Syndrome. In the proposed work fuzzy logic approach is used with two separate modules as disease diagnosis and expert learning.

\section{DESIGN OF WEB BASED EXPERT SYSTEM FOR DIABETES RISK ASSESSMENT (WEB-FESSRADM)}

\subsection{Configuration of Fuzzy Expert System}

The configuration of fuzzy expert system consist four components: fuzzification, knowledge base, decision making logic and defuzzification. Before starting the procedure of system design we have to choose the input and output variables. Selection of these variables depends on expert knowledge of the system [6].

Fuzzification:

It is an important concept of fuzzy logic theory. Fuzzification is the process where crisp value transformed into fuzzy value. The conversion of crisp to fuzzy is done by the membership functions.

Knowledge base:

It contains information and knowledge of application domain. It consists the database having data about system processes and a linguistic rule base which consists the strategies and goals in the form of control rules.

Decision making logic:

It performs tasks like simulating the decision making procedures by fuzzy logic concepts and inferencing by linguistic rule base, fuzzy operators, implication and aggregation

Defuzzification:

It converts aggregation output into crisp value by using defuzzification strategies. Selection of defuzzification strategy among many is depends on properties of application because of absence of selection procedure.

\subsection{Data Collection}

The availability and accessibility of significant data on considered domain impacts the study and research. The collection and organization of information requires considerable resources and time. For proposed study, data accumulation was done from 'Swad' diabetes care centre, Sangli, Maharashtra. Amid patients visit to the centre, data was gathered in written from patients or noted down against oral response of patients. This procedure of data accumulation was relying upon the patient's instructive foundation. With proper questionnaire and smooth interaction with patients their own, symptoms, previous history and gender specific information was recorded. Additionally physical examination data and recommended lab tests data was recorded. 60 patients' information was collected which comprised of symptomatic and patho-physiological information.

\subsection{Data Selection and Distribution}

The input variables for Web-FESSRADM are the symptoms of Diabetes. For proposed study 10 diabetes symptoms are used as input variables by taking concern of domain experts. The input variables are Polyuria, Polydipsia, Polyphagia Nocturia, Giddiness, Recurrent Boils, Weight Loss, Recurrent Urinary Tract Infections, Vision Changes and Candidal Infections. The output variable is Risk Assessment of Diabetes Mellitus (SRADM). Category wise variables with their codes are given in Table 1. Variable codes are used as and when required for input and output variables in system design.

Table 1. Input and Output Variables

\begin{tabular}{|c|c|c|c|}
\hline Sr.No & Category & Variable & Codes \\
\hline 1 & \multirow{10}{*}{ Input } & Polyuria & $\mathrm{PU}$ \\
\hline 2 & & Polydipsia & PD \\
\hline 3 & & Polyphagia & PP \\
\hline 4 & & Nocturia & $\mathrm{NC}$ \\
\hline 5 & & Giddiness & GD \\
\hline 6 & & Recurrent Boils & $\mathrm{RB}$ \\
\hline 7 & & Weight Loss & WL \\
\hline 8 & & Recurrent Urinary & UI \\
\hline 9 & & Vision Changes & $\mathrm{VC}$ \\
\hline 10 & & Candidal Infections & $\mathrm{CI}$ \\
\hline 11 & Output & $\begin{array}{l}\text { Risk Assessment of } \\
\text { Diabetes Mellitus }\end{array}$ & SRADM \\
\hline
\end{tabular}

\subsection{Modeling of Input, Output Variables}

The linguistic variables (LV) and its fuzzy values (linguistic variable's ranges) are used in proposed study by having long chain of discussions with domain experts. For the input variables like polyuria, polydipsia, polyphagia and nocturia fuzzy set values of linguistic variables are decided by considering normal environmental condition and physical activity where as for other input variables and output variable input values like 1,2 and 3 are decided and shown in Table 2 and Table 3.

\subsection{Web-FESSRADM System Architecture}

Web-FESSRADM architecture is presented in Figure-1 for symptomatic diabetes risk identification. It includes user interface which runs as client side and enables users to select symptoms and to insert fuzzy linguistic variable values to check risk. The UI is designed with HTML, CSS and JavaScript. At server side, user input is given to the fuzzy inference engine which produces result using knowledge base. The Knowledge Base consist rule set which represents 
Table 2. Input Variables with Fuzzy Values

\begin{tabular}{|l|l|l|l|l|l|l|l|}
\hline \multicolumn{2}{|l}{ Symptoms as Fuzzy Variables } \\
\hline
\end{tabular}

Table 3. Input and Output variables with Fuzzy Input Values

\begin{tabular}{|c|c|c|c|c|c|c|c|c|}
\hline $\begin{array}{c}\text { Symptoms } \\
\text { as Fuzzy } \\
\text { Variables -> }\end{array}$ & Giddiness & $\begin{array}{c}\text { Recurrent } \\
\text { Boils }\end{array}$ & $\begin{array}{c}\text { Weight } \\
\text { Loss }\end{array}$ & $\begin{array}{c}\text { Recurrent } \\
\text { Urinary } \\
\text { Tract } \\
\text { Infections }\end{array}$ & $\begin{array}{c}\text { Vision } \\
\text { Changes }\end{array}$ & $\begin{array}{c}\text { Candidal } \\
\text { Infections }\end{array}$ & $\begin{array}{c}\text { Output } \\
\text { Variable } \\
\text { SRADM }\end{array}$ & Input Value \\
\hline \multirow{3}{*}{ LV } & very_rare & very_rare & very_less & very_less & very_less & very_rare & mild & 1 \\
\cline { 2 - 9 } & rare & rare & less & Less & less & rare & moderate & 2 \\
\cline { 2 - 9 } & often & often & more & More & more & often & severe & 3 \\
\hline
\end{tabular}

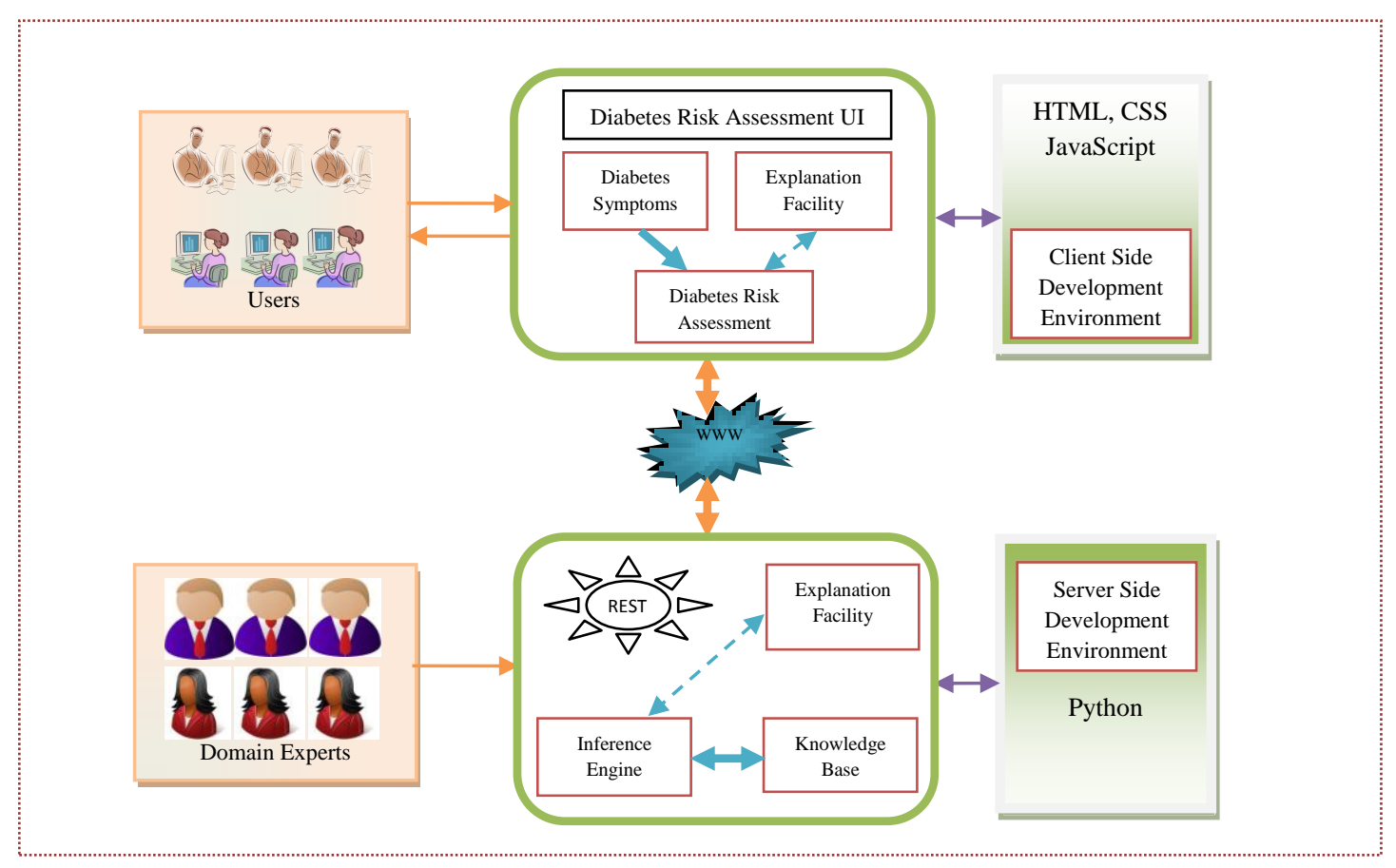

Figure 1: Web-FESSRADM Architecture

knowledge shared by the domain experts. Inference mechanism and Knowledge Base is designed using Python programming language. The World Wide Web makes WebFESSRADM accessible online.

\subsection{Development Methodology}

\subsubsection{Definition of linguistic variables}

For proposed study the input variables are Polyuria, Polydipsia, Polyphagia, Nocturia Giddiness, Recurrent Boils, Weight Loss, Recurrent Urinary Tract Infections, Vision Changes and Candidal Infections selected. The output variable is Risk Assessment of Diabetes Mellitus (SRADM). The set of linguistic variables are shown in Table 2 and Table 3.

\subsubsection{Determination of fuzzy set and fuzzy operator}

Fuzzy set demonstrates the organization and information about the input and output variables. In fuzzy sets, each variable is mapped into $[0,1]$ by using membership function [20].

$\mu \mathrm{V}: \mathrm{X} \longrightarrow\{0,1\}$ where value of $\mathrm{X}$ is real numbers from 0 to 1 including 0 and 1 . 
For proposed work fuzzy sets are determined for polyuria(less_frequent, average, more_frequent), polydipsia (less_thirsty, average, more_thirsty), polyphagia(less_hungry, average, more_hungry), nocturia(less_frequent, frequent, more_frequent), giddiness(very_rare, rare, often), recurrent boils(very_rare, rare, often), weight loss(very_less, less, mor e), recurrent urinary tract infections(very_less, less, more) vision changes(very_less, less, more), candidal infection(very_less, less, more) and SRADM(mild, moderate severe). S Norms (Fuzzy Union) and $\mathrm{T}$ Norms (Fuzzy Intersection) are Fuzzy operators [18][20]. For proposed study S norm (Fuzzy Union) operator is used.

\subsubsection{Fuzzi fication}

In this research paper for fuzzification triangular membership function is used which shown in equation (1). It is represented using three points as $(a, b, c)[6]$. Although there is no theory for choice of membership function but only constraint that it should satisfy the value within range of 0 to 1 .

$$
\mu_{A}(x)= \begin{cases}0 & \text { if } x<a \\ x-a / b-a & \text { if } a<=x<=b \\ c-x / c-b & \text { if } b<x<=c \\ 0 & \text { if } x>c\end{cases}
$$

The fuzzy triangular parameters $[a, b, c]$ for each variable is determined by having concern with system domain experts and shown in Table 4.

For the triangular fuzzy number polyuria (less_frequent) = $[1,3,5]$ the membership function will be as in eq. (2).

$$
\mu_{\text {les__frequent }}(x)= \begin{cases}0 & \text { if } x<1 \\ x-1 / 2 & \text { if } 1<=x<=3 \\ 3-x / 2 & \text { if } 3<x<=5 \\ 0 & \text { if } x>5\end{cases}
$$

Membership function graphics for fuzzy variables Polyuria and Nocturia is shown in Figure 3 and Figure 4.

Table 4. Fuzzy Triangular Parameters

\begin{tabular}{|l|l|l|}
\hline Fuzzy Variables & $\begin{array}{l}\text { Linguistic } \\
\text { Variables }\end{array}$ & $\begin{array}{l}\text { Fuzzy Triangular } \\
\text { Parameters }\end{array}$ \\
\hline \multirow{4}{*}{ Polyuria } & less_frequent & {$[1,3,5]$} \\
\cline { 2 - 3 } & average & {$[4,6,9]$} \\
\cline { 2 - 3 } & more_frequent & {$[8,11,20]$} \\
\hline \multirow{4}{*}{ Polydipsia } & less_thirsty & {$[1,2,4]$} \\
\cline { 2 - 3 } & average & {$[3,5,8]$} \\
\cline { 2 - 3 } & more_thirsty & {$[7,9,15$} \\
\hline \multirow{4}{*}{ Nocturia } & less_hungry & {$[1,2,3]$} \\
\cline { 2 - 3 } & average & {$[2,3,5]$} \\
\cline { 2 - 3 } & more_hungry & {$[4,6,10]$} \\
\hline \multirow{3}{*}{ Giddiness } & less_frequent & {$[0,1,2]$} \\
\cline { 2 - 3 } & frequent & {$[1,3,4]$} \\
\cline { 2 - 3 } & more_frequent & {$[3,5,10]$} \\
\hline Recurrent Boils & very_rare & {$[0,0,1]$} \\
\cline { 2 - 3 } & rare & {$[1,1,2]$} \\
\cline { 2 - 3 } & often & {$[1,2,3]$} \\
\hline
\end{tabular}

\begin{tabular}{|l|l|l|}
\hline \multirow{4}{*}{ Weight Loss } & rare & {$[1,1,2]$} \\
\cline { 2 - 3 } & often & {$[1,2,3]$} \\
\hline \multirow{3}{*}{$\begin{array}{l}\text { Recurrent Urinary } \\
\text { Tract Infections }\end{array}$} & very_less & {$[0,0,1]$} \\
\cline { 2 - 3 } & less & {$[1,1,2]$} \\
\cline { 2 - 3 } & more & {$[1,2,3]$} \\
\cline { 2 - 3 } & less & {$[0,0,1]$} \\
\hline \multirow{3}{*}{ Vision Changes } & vere & {$[1,1,2]$} \\
\cline { 2 - 3 } & less_less & {$[1,2,3]$} \\
\cline { 2 - 3 } & more & {$[0,0,1]$} \\
\hline \multirow{2}{*}{$\begin{array}{c}\text { Candidal } \\
\text { Infections }\end{array}$} & very_rare & {$[1,1,2]$} \\
\cline { 2 - 3 } & rare & {$[1,2,3]$} \\
\cline { 2 - 3 } & often & {$[0,0,1]$} \\
\hline \multirow{3}{*}{ SRADM } & mild & {$[1,1,2]$} \\
\cline { 2 - 3 } & moderate & {$[2,4,6]$} \\
\cline { 2 - 3 } & severe & {$[5,7,10]$} \\
\hline
\end{tabular}

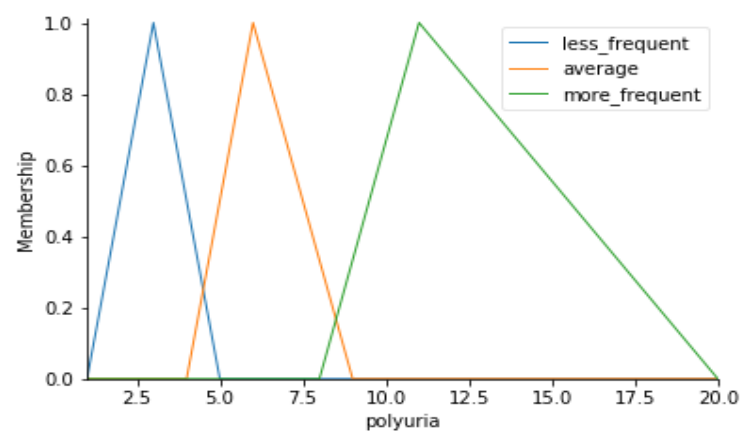

Figure 2: Membership graphics of fuzzy variable Polyuria.

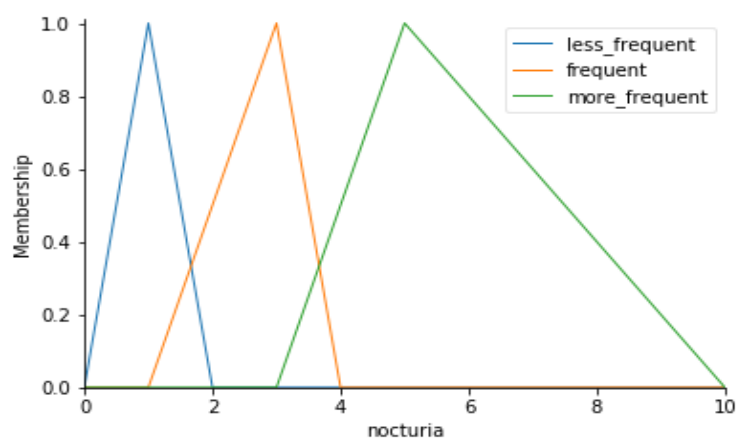

Figure 3: Membership graphics of fuzzy variable Nocturia.

\subsubsection{Designing Rule Base}

A fuzzy rule base contains a fuzzy rule which is in the form of $\mathrm{R} 1$ : If $\mathrm{x}$ is $\mathrm{A}$ then $\mathrm{y}$ is $\mathrm{B}$. where $\mathrm{A}$ and $\mathrm{B}$ are linguistic values of defined fuzzy set. 'IF' part of fuzzy rule is called antecedent or premise and 'Then' part is called as consequence or conclusion. The antecedent and consequence of the rule is represented by linguistic variables. The rule base for proposed study is designed with assistance of domain experts. There are 60 rules in the knowledge base of proposed work. Some of the rules from rule base are given below. 
Rule1 = If (PU is less_frequent $)$ or (PD is less_thirsty ) or (PP is less_hungry ) or (NC is less_frequent) or (RB is very_rare ) or (GD is very_rare) or (WT is very_less ) or (UI is very_less ) or (VC is very_less ) or (CI is very_rare) then (SRADM is mild) Rule2 = If ( $\mathrm{PU}$ is average ) or (PD is average ) or ( $\mathrm{PP}$ is average ) or ( $\mathrm{NC}$ is frequent ) or ( $\mathrm{RB}$ is rare ) or (GD is rare ) or (WT is less ) or ( UI is less) or ( $\mathrm{VC}$ is less ) or ( $\mathrm{CI}$ is rare) then (SRADM is moderate) Rule3 = If (PU is more_frequent ) or ( PD is more_thirsty ) or ( $\mathrm{PP}$ is more_hungry ) or ( $\mathrm{NC}$ is more_frequent ) or ( $\mathrm{RB}$ is often ) or (GD is often ) or ( WT is more) or ( UI is more ) or ( $\mathrm{VC}$ is (more ) or ( $\mathrm{CI}$ is often) then (SRADM is severe) Rule4 = If (PU is less_frequent ) or ( PD is less_thirsty ) or (PP is less_hungry) or ( NC is less_frequent) or (RB is very_rare ) or ( GD is very_rare ) or ( WT is very_less ) or ( UI is less ) or ( VC is less ) or ( $\mathrm{CI}$ is rare) then (SRADM is mild) Rule5 = If (PU is less_frequent) or ( PD is less_thirsty ) or

( $\mathrm{PP}$ is less_hungry) or ( $\mathrm{NC}$ is less_frequent ) or ( $\mathrm{RB}$ is very_rare ) or ( GD is very_rare) or (WT is very_less ) or

( UI is more ) or (VC is more) or ( $\mathrm{CI}$ is often) then

( $\mathrm{SRADM}$ is moderate)

Rule6 = If (PU is more_frequent ) or ( PD is more_thirsty ) or ( PP is more_hungry) or ( NC is more_frequent ) or ( $\mathrm{RB}$ is very_rare ) or ( GD is very_rare') or ( WT is very_less ) or ( $\mathrm{UI}$ is very_less ) or ( $\mathrm{VC}$ is very_less) or ( $\mathrm{CI}$ is very_rare ) then ( SRADM is severe)

\subsubsection{Decision making logic}

The decision making logic i.e. fuzzy inference is method of mapping the input to an output [19]. In the proposed system Mamdani Inference method is used. It has four steps through which it executes: fuzzification of the input variables, evaluation of rules, aggregation of the rule outputs and defuzzification [19]. Once crisp values of input variables are obtained they are fuzzified over the membership function against fuzzy sets.

Fuzzified inputs then applied on premise of fuzzy rules. The membership functions of fuzzy variables are applied to determine degree of truth value of premise of each rule. In case of multiple premises of the fuzzy rule, AND or OR fuzzy operators are used to get single result value of premises evaluation. In present work OR fuzzy operator is used. The result value of premise of the rule applied to the membership function of the conclusion part. This process is repeated for each fuzzy rule. Aggregation is the unification process where outputs of all fuzzy rules clipped and scaled and combined into single fuzzy set of each output variable.

\subsubsection{Defuzzification}

The final step of inference process is defuzzification which takes aggregate output generated as input and translates into single crisp value as output. There are several defuzzification techniques. There is no known process to select defuzzification technique among many. Mean of Maximum(MOM), Bisector of Area(BOA) and Center of Area (COA) are commonly used defuzzification techniques [6]. The defuzzification technique Center of Area (COA) also known as Center of Gravity (COG) is used to convert fuzzy conclusion into crisp value.

\subsection{Proposed Algorithm for Symptomatic Risk Assessment of Diabetes Mellitus INPUT}

The crisp values for Polyuria, Polydipsia, Polyphagia, Nocturia, Giddiness, Recurrent Boils, Weight loss, Recurrent
Urinary tract infections, Vision changes and Candidal infections

\section{OUTPUT}

The crisp value for SRADM

Begin

Step 1: Generating the fuzzy numbers for Polyuria, Polydipsia, Polyphagia, Nocturia, Giddiness, Recurrent Boils Weight loss, Recurrent urinary tract infections, Vision changes and Candidal infections.

Step 2: Generating the fuzzy number for SRADM for the output.

Step 3: Input the crisp values of fuzzy variables (Polyuria, Polydipsia, Polyphagia, Nocturia, Giddiness, Recurrent Boils Weight loss, Recurrent Urinary tract infections, Vision changes and Candidal infections)

Step 4: Setting the triangular membership function for each linguistic variable of fuzzy variables.

Step 5: The associated triangular membership function is calculated for each linguistic variable.

Step 6: Execution of Fuzzy inference mechanism by

Mamdani's method.

Step 7: Defuzzification for the crisp value by Centre of Area (COA) technique.

$$
\text { SRADM }=\frac{\sum_{\mathrm{i}=1}^{\mathrm{n}} \mu_{\mathrm{A}}\left(\mathrm{x}_{\mathrm{i}}\right) \cdot \mathrm{x}_{\mathrm{i}}}{\sum_{\mathrm{i}=1}^{\mathrm{n}} \mu_{\mathrm{A}}\left(\mathrm{x}_{\mathrm{i}}\right)}
$$

Where $\mathrm{n}$ is the number quantization levels of the output, $\mathrm{A}$ is fuzzy set defined on dimension $\mathrm{x}$ [18].

Step 8: Representing the SRADM value in human understandable language.

End.

\section{SYSTEM DEVELOPMENT (WEB-FESSRADM)}

The proposed study presents the web based expert system (Web-FESSRADM) for symptomatic risk identification of diabetes. Research work in [4] has shown that online expert system can be considered as web engineering project which can be developed by combining expert system development with web site development. The proposed system development is carried out using traditional software development methodology (SDLC) combining with fuzzy expert system development techniques.

\subsection{Development Environment}

Python 3.6.3 programming language and Flask micro framework has been chosen for the development of WebFESSRADM. Python is highly usable in research of recent times because of its richness and availability of open source libraries for wide ranges of research areas. Graphical User Interface of the system is designed with HTML5, Bootstrap and CSS. JavaScript is used for client side scripting. 


\subsection{Code Samples}

\subsubsection{Code for setting universe of discourse for input variables}

$\mathrm{PU}=$ ctrl.Antecedent (np.arange $(1,21, \quad 1), \quad$ 'PU') $\mathrm{PD}=$ ctrl.Antecedent (np.arange $(1,16,1), \quad$ 'PD') $\mathrm{PP}=$ ctrl.Antecedent $\left(\mathrm{np}\right.$.arange $\left.(1,11,1), \mathrm{PP}^{\prime}\right)$

$\mathrm{NC}=$ ctrl.Antecedent $\left(\mathrm{np}\right.$.arange $(0,11,1),{ }^{\mathrm{NC}}$ ')

\subsubsection{Code for setting triangular membership} function for fuzzy linguistic variables

PU ['less_frequent'] = fuzz.trimf $($ PU.universe, $[1,3,5])$

PU ['average'] $=$ fuzz.trimf ( PU.universe, $[4,6,9]$ )

PU ['more_frequent'] = fuzz.trimf $($ PU.universe, $[8,11,20])$

\subsubsection{Rule base}

rule1 = ctrl.Rule(PU['less_frequent'] | PD['less_thirsty'] PP['less_hungry'] | NC['less_frequent'] | RB['very_rare'] GD['very_rare'] | WL['very_less'] | UI['very_less'] | VC['very_less'] | CI['very_rare'], $\quad$ SRADM['mild'])

rule2 = ctrl.Rule(PU['average'] | PD['average'] | PP['average']| $\mathrm{NC}$ ['frequent'] | RB['rare'] | GD['rare'] | WL['less']| UI['less'] | VC['less'] | CI['rare'], SRADM['moderate'])

\subsubsection{Input-output Interface}

Figure 3 shows input interface from where user enters crisp values for each input variables i.e. for diabetes symptoms.

Figure 4 shows out interface where diabetes risk assessment result is displayed in the form crisp value as well as in human understandable form i.e. in the form of linguistic as output.

\section{RESULT AND DISCUSSION}

Performance of the proposed system is measured by its accuracy of predicting diabetes risk with comparing to medical practitioners opinion. Following Table 5 shows the experts or doctors' opinion and the output of the proposed system for symptomatic data of 10 patients. The highlighted cells of Table 5 show incorrect conclusions. The proposed system is tested for 60 patient's symptomatic data and we got 90\% accuracy which matches the expert opinion.

\section{CONCLUSION}

Use of fuzzy logic in medical diagnosis has proven its importance in designing of fuzzy expert systems which draw better diagnosis conclusions. The work presented in this paper introduces very simple methodology using fuzzy logic to assess diabetes risk using its symptoms. The WebFESSRADM is designed for people to check their diabetes risk as step towards self-management and diabetes education and for doctors, practitioners and experts to assess diabetes risk. It is attempt to spread awareness about diabetes risk assessment among the people. Proposed work can be extended further by adding another set of diabetes symptoms and diabetes complications. The work will be extended to tune the rule base of present study and to add expert system modules for diabetes diagnosis and its management.

\section{ACKNOWLEDGEMENT}

Researchers would like to express gratitude to Dr. Kapil Patil, 'Swad' Diabetes Care Centre, Sangli for immense helping hands in data collection and valuable guidance and assistance for this research.

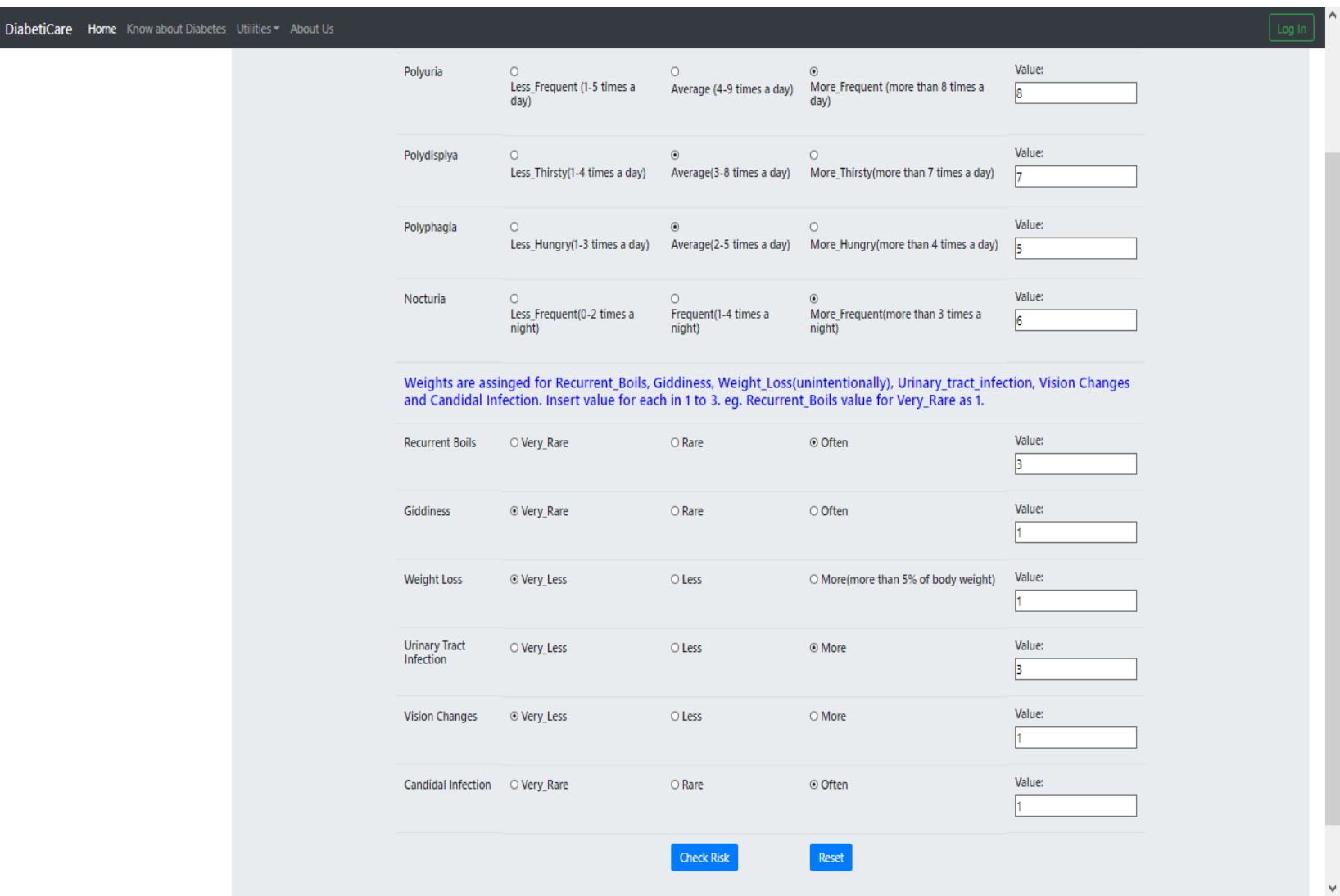

Figure 4: Interface for insert crisp values of Symptoms 
Diabetes Risk Assessment using Symptoms

Your Diabetes Risk is at 4.68 of $0-10$ Risk Range

You have Moderate Diabetes Risk

Back to Symptoms Page

Figure 5: Result screen of Diabetes Risk Assessment

Table. 5 Doctors Opinion and System Result

\begin{tabular}{|c|c|c|c|c|c|c|c|c|c|c|c|c|}
\hline $\begin{array}{l}\text { Patien } \\
t \text { ID }\end{array}$ & $\mathbf{P U}$ & PD & PP & $\mathrm{NC}$ & GD & $\mathbf{R B}$ & WL & $\mathbf{U I}$ & VC & CI & $\begin{array}{l}\text { Practitione } \\
\text { r/Expert } \\
\text { Oninion }\end{array}$ & $\begin{array}{l}\text { System } \\
\text { Output }\end{array}$ \\
\hline PID01 & $\begin{array}{l}\text { Averag } \\
\mathrm{e}\end{array}$ & $\begin{array}{l}\text { Less } \\
\text { Thirsty }\end{array}$ & $\begin{array}{l}\text { Less } \\
\text { Hungry }\end{array}$ & $\begin{array}{l}\text { Frequen } \\
\mathrm{t}\end{array}$ & $\begin{array}{l}\text { Ver } \\
\text { y }\end{array}$ & $\begin{array}{l}\text { Rar } \\
\mathrm{e}\end{array}$ & Less & $\begin{array}{l}\text { Very } \\
\text { Less }\end{array}$ & $\begin{array}{l}\text { Very } \\
\text { Less }\end{array}$ & $\begin{array}{l}\text { Very } \\
\text { Rare }\end{array}$ & $\begin{array}{l}\text { Moderatly } \\
\text { symptomati }\end{array}$ & $\begin{array}{l}\text { Moderat } \\
\mathrm{e}\end{array}$ \\
\hline PID02 & $\begin{array}{l}\text { More } \\
\text { Frequen }\end{array}$ & $\begin{array}{l}\text { More } \\
\text { Thirsty }\end{array}$ & $\begin{array}{l}\text { Less } \\
\text { Hungry }\end{array}$ & $\begin{array}{l}\text { Frequen } \\
\mathrm{t}\end{array}$ & $\begin{array}{l}\text { Ver } \\
\mathrm{y}\end{array}$ & $\begin{array}{l}\text { Ver } \\
\mathrm{y}\end{array}$ & Less & Less & More & Often & $\begin{array}{l}\text { Severely } \\
\text { symptomati }\end{array}$ & Severe \\
\hline PID03 & $\begin{array}{l}\text { Averag } \\
\mathrm{e}\end{array}$ & $\begin{array}{l}\text { Less } \\
\text { Thirsty }\end{array}$ & $\begin{array}{l}\text { Less } \\
\text { Hungry }\end{array}$ & $\begin{array}{l}\text { More } \\
\text { Frequen }\end{array}$ & $\begin{array}{l}\text { Ver } \\
\mathrm{y}\end{array}$ & $\begin{array}{l}\text { Ver } \\
\mathrm{y}\end{array}$ & More & $\begin{array}{l}\text { Very } \\
\text { Less }\end{array}$ & $\begin{array}{l}\text { Very } \\
\text { Less }\end{array}$ & $\begin{array}{l}\text { Very } \\
\text { Rare }\end{array}$ & $\begin{array}{l}\text { Moderatly } \\
\text { symptomati }\end{array}$ & $\mathrm{Mc}$ \\
\hline PID04 & $\begin{array}{l}\text { Less } \\
\text { Frequen }\end{array}$ & $\begin{array}{l}\text { Averag } \\
\text { e }\end{array}$ & $\begin{array}{l}\text { Averag } \\
\mathrm{e}\end{array}$ & $\begin{array}{l}\text { Frequen } \\
\mathrm{t}\end{array}$ & $\begin{array}{l}\text { Ver } \\
\mathrm{y}\end{array}$ & $\begin{array}{l}\text { Ver } \\
\mathrm{y}\end{array}$ & $\begin{array}{l}\text { Very } \\
\text { Less }\end{array}$ & Less & $\begin{array}{l}\text { Very } \\
\text { Less }\end{array}$ & $\begin{array}{l}\text { Very } \\
\text { Rare }\end{array}$ & $\begin{array}{l}\text { Mildy } \\
\text { symptomati }\end{array}$ & Mild \\
\hline PID05 & $\begin{array}{l}\text { Averag } \\
\mathrm{e}\end{array}$ & $\begin{array}{l}\text { More } \\
\text { Thirsty }\end{array}$ & $\begin{array}{l}\text { More } \\
\text { Hungry }\end{array}$ & $\begin{array}{l}\text { More } \\
\text { Frequen }\end{array}$ & $\begin{array}{l}\text { Ver } \\
\mathrm{y}\end{array}$ & $\begin{array}{l}\text { Ver } \\
\mathrm{y}\end{array}$ & More & More & $\begin{array}{l}\text { Very } \\
\text { Less }\end{array}$ & Often & $\begin{array}{l}\text { Severly } \\
\text { symtomatic }\end{array}$ & $\mathrm{Se}$ \\
\hline PID06 & $\begin{array}{l}\text { Less } \\
\text { Frequen }\end{array}$ & $\begin{array}{l}\text { Averag } \\
\mathrm{e}\end{array}$ & $\begin{array}{l}\text { Less } \\
\text { Hungry }\end{array}$ & $\begin{array}{l}\text { Less } \\
\text { Frequen }\end{array}$ & $\begin{array}{l}\text { Rar } \\
\mathrm{e}\end{array}$ & $\begin{array}{l}\text { Ver } \\
\mathrm{y}\end{array}$ & $\begin{array}{l}\text { Very } \\
\text { Less }\end{array}$ & $\begin{array}{l}\text { Very } \\
\text { Less }\end{array}$ & $\begin{array}{l}\text { Very } \\
\text { Less }\end{array}$ & $\begin{array}{l}\text { Very } \\
\text { Rare }\end{array}$ & $\begin{array}{l}\text { Mildy } \\
\text { symptomati }\end{array}$ & Mild \\
\hline PID07 & $\begin{array}{l}\text { Averag } \\
\mathrm{e}\end{array}$ & $\begin{array}{l}\text { Averag } \\
\mathrm{e}\end{array}$ & $\begin{array}{l}\text { Averag } \\
\mathrm{e}\end{array}$ & $\begin{array}{l}\text { Frequen } \\
\mathrm{t}\end{array}$ & $\begin{array}{l}\text { Ver } \\
\mathrm{y}\end{array}$ & $\begin{array}{l}\text { Ver } \\
\mathrm{y}\end{array}$ & Less & More & $\begin{array}{l}\text { Very } \\
\text { Less }\end{array}$ & Often & $\begin{array}{l}\text { Severly } \\
\text { symtomatic }\end{array}$ & Moderate \\
\hline PID08 & $\begin{array}{l}\text { Averag } \\
\mathrm{e}\end{array}$ & $\begin{array}{l}\text { Averag } \\
\mathrm{e}\end{array}$ & $\begin{array}{l}\text { Less } \\
\text { Hungry }\end{array}$ & $\begin{array}{l}\text { Frequen } \\
\mathrm{t}\end{array}$ & $\begin{array}{l}\text { Ver } \\
\mathrm{y}\end{array}$ & $\begin{array}{l}\text { Ver } \\
\mathrm{y}\end{array}$ & $\begin{array}{l}\text { Very } \\
\text { Less }\end{array}$ & $\begin{array}{l}\text { Very } \\
\text { Less }\end{array}$ & $\begin{array}{l}\text { Very } \\
\text { Less }\end{array}$ & $\begin{array}{l}\text { Very } \\
\text { Rare }\end{array}$ & $\begin{array}{l}\text { Moderatly } \\
\text { symptomati }\end{array}$ & Moderate \\
\hline PID09 & $\begin{array}{l}\text { Less } \\
\text { Frequen }\end{array}$ & $\begin{array}{l}\text { Less } \\
\text { Thirsty }\end{array}$ & $\begin{array}{l}\text { Less } \\
\text { Hungry }\end{array}$ & $\begin{array}{l}\text { Less } \\
\text { Frequen }\end{array}$ & $\begin{array}{l}\text { Ver } \\
\mathrm{y}\end{array}$ & $\begin{array}{l}\text { Ver } \\
\mathrm{y}\end{array}$ & $\begin{array}{l}\text { Very } \\
\text { Less }\end{array}$ & $\begin{array}{l}\text { Very } \\
\text { Less }\end{array}$ & $\begin{array}{l}\text { Very } \\
\text { Less }\end{array}$ & $\begin{array}{l}\text { Very } \\
\text { Rare }\end{array}$ & $\begin{array}{l}\text { Mildy } \\
\text { symptomati }\end{array}$ & Mild \\
\hline $\begin{array}{l}\text { PID01 } \\
0\end{array}$ & $\begin{array}{l}\text { Averag } \\
\mathrm{e}\end{array}$ & $\begin{array}{l}\text { Less } \\
\text { Thirsty }\end{array}$ & $\begin{array}{l}\text { Less } \\
\text { Hungry }\end{array}$ & $\begin{array}{l}\text { Frequen } \\
\mathrm{t}\end{array}$ & $\begin{array}{l}\text { Ver } \\
\mathrm{y}\end{array}$ & $\begin{array}{l}\text { Ver } \\
\mathrm{y}\end{array}$ & Less & $\begin{array}{l}\text { Very } \\
\text { Less }\end{array}$ & $\begin{array}{l}\text { Very } \\
\text { Less }\end{array}$ & $\begin{array}{l}\text { Very } \\
\text { Rare }\end{array}$ & $\begin{array}{l}\text { Moderatly } \\
\text { symptomati }\end{array}$ & Mild \\
\hline
\end{tabular}

\section{REFERENCES}

[1] American Diabetes Association. "Diagnosis and classification of diabetes mellitus." Diabetes care 33.Suppl 1 (2010): S62.

[2] Samuel, Oluwarotimi Williams, M. O. Omisore, and B. A. Ojokoh. "A web based decision support system driven by fuzzy logic for the diagnosis of typhoid fever." Expert Systems with Applications 40.10 (2013): 4164-4171.

[3] Li, Daoliang, Zetian Fu, and Yanqing Duan. "FishExpert: a web-based expert system for fish disease diagnosis." Expert systems with Applications 23.3 (2002): 311-320.

[4] Dokas, Ioannis M. "Developing Web Sites For Web Based Expert Systems: A Web Engineering Approach." ITEE. 2005.

[5] Malmir, Behnam, Mohammadhossein Amini, and Shing I. Chang. "A medical decision support system for disease diagnosis under uncertainty." Expert Systems with Applications 88 (2017): 95-108.
[6] Lee, Kwang Hyung. First course on fuzzy theory and applications. Vol. 27. Springer Science \& Business Media, 2006.

[7] Huang, Mu-Jung, and Mu-Yen Chen. "Integrated design of the intelligent web-based Chinese Medical Diagnostic System (CMDS)-Systematic development for digestive health." Expert Systems with Applications 32.2 (2007): 658-673.

[8] Phuong, Nguyen Hoang, and Vladik Kreinovich. "Fuzzy logic and its applications in medicine." International journal of medical informatics 62.2-3 (2001): 165-173.

[9] Djam, X. Y., et al. "A fuzzy expert system for the management of malaria." (2011).

[10] Akinyokun, Oluwole Charles, et al. "Fuzzy logic-driven expert system for the diagnosis of heart failure disease." Artificial Intelligence Research 4.1 (2014): 12.

[11] Hasan, Mir Anamul, and Ahsan Raja Chowdhury. "Human disease diagnosis using a fuzzy expert system." arXiv preprint arXiv:1006.4544 (2010). 
[12] Tripathi, Brajendra Kumar, and Arvind Kumar Srivastava. "Diabetes mellitus: Complications and therapeutics." Medical science monitor 12.7 (2006): RA130-RA147.

[13] Duan, Yanqing, John S. Edwards, and M. X. Xu. "Webbased expert systems: benefits and challenges." Information \& Management 42.6 (2005): 799-811.

[14] Power, Daniel J. "Web-based and model-driven decision support systems: concepts and issues." AMCIS 2000 Proceedings (2000): 387.

[15] Grove, Ralph. "Internet- based expert systems." Expert systems 17.3 (2000): 129-135.

[16] Mujawar, Irfan \& $\mathrm{T}$ Jadhav, B. (2017). COMPREHENSIVE STUDY ON WEB BASED
EXPERT SYSTEMS FOR DISEASE DIAGNOSIS AND TREATMENT. International Journal of Computer Engineering and Applications. XI.

[17] Baghel, M. K., \& Mehta, M. N. A Web Based Fuzzy Expert System for Human Disease Diagnosis. International Journal of Engineering And Computer Science ISSN, 2319-7242.

[18] Wang, Li-Xin. A course in fuzzy systems. Prentice-Hall press, USA, 1999.

[19] Tsoukalas, Lefteri H., and Robert E. Uhrig. Fuzzy and neural approaches in engineering. John Wiley \& Sons, Inc., 1996.

[20] Siler, William, and James J. Buckley. Fuzzy expert systems and fuzzy reasoning. John Wiley \& Sons, 2005. 